\title{
Evaluasi Kandungan Glukosa Dan Indeks Glikemik Beberapa Sumber Karbohidrat Dalam Upaya Penggalian Pangan Ber-Indeks Glikemik Rendah
}

Nuzul Wahyuning Diyah*, Aprilia Ambarwati, Gita M. Warsito, Greta Niken, Eriza T. Heriwiyanti, Rany Windysari, Deka Prismawan, Robi'atul F. Hartasari \& Purwanto

Faculty of Pharmacy Universitas Airlangga, Surabaya

*Corresponding author: nuzul_wd@yahoo.com

\begin{abstract}
Background: Various studies have shown that low glycemic index (GI) diet can lower insulin resistance in people with Diabetes Mellitus. The main problem in low GI diet is the availability of low GI foods while the staple food of most Indonesian people is rice, which is classified as high GI food. Objective: The research was conducted to evaluate glucose content and glycemic index of various carbohydrate-containing foods in order to find the low GI foods for diabetic people. Methods: The sample foods include whole grains (brown rice, corn, sorghum), tubers (cassava, bentul), fruits (banana var ambon and kepok, breadfruit), and legumes (mung beans, kidney beans). The glucose content was determined by Luff-Schoorl method and the glycemic index was assayed using experimental animals (rabbits) against standard food, glucose $0.47 \mathrm{~g} / \mathrm{Kg}$ body weight. Food samples were administered in an amount equivalent to glucose content in each processed foods. Results: Glucose content represented by total reducing sugars contained in the tested foods vary depending on character of starch in the carbohydrate-containing foods. All the tested food has lower GI than white rice, but steam-cooked cassava and bentul still relatively high GI foods. Conclusions: Except the cassava and bentul,all the tested foods are carbohydrate-containing foods which is recommended for diabetic people.
\end{abstract}

Keywords: carbohydrate-containing foods, glucose content, low glycemic index

\begin{abstract}
Abstrak
Pendahuluan: Berbagai penelitian menunjukkan bahwa diet makanan ber-Indeks Glikemik (IG) rendah mampu menurunkan resistensi insulin pada penderita Diabetes Mellitus. Masalah utama dalam diet pangan IG rendah adalah ketersediaan bahan pangan dengan IG rendah sementara makanan pokok sebagian besar penduduk Indonesia adalah nasi, yang tergolong pangan dengan IG tinggi.Tujuan: menentukan kandungan glukosa dan indeks glikemik beberapa bahan pangan sumber karbohidrat dari kelompok biji-bijian (beras merah, jagung, sorgum), umbi-umbian (singkong, bentul), buah-buahan (pisang kapok, pisang ambon, sukun), serta kacang-kacangan (kacang hijau, kacang merah), untuk memperoleh bahan pangan sumber karbohidrat ber-IG rendah sebagai pangan alternatif pengganti nasi dalam diet penderita Diabetes Mellitus. Metode: Kadar glukosa ditentukan dengan metode Luff-Schoorl dan penentuan indeks glikemik dilakukan menggunakan hewan coba kelinci terhadap pangan standar, glukosa $0.47 \mathrm{~g} / \mathrm{Kg}$ berat badan. Sampel pangan uji diberikan dalam jumlah yang setara dengan kandungan glukosa dalam setiap pangan uji. Hasil: Kandungan glukosa yang ditetapkan sebagai gula pereduksi total dalam pangan uji bervariasi, bergantung pada karakter pati dalam pangan sumber karbohidrat. Semua pangan uji memiliki indeks glikemik yang lebih rendah dibanding nasi putih, tetapi singkong kukus dan bentul kukus masih tergolong pangan IG tinggi. Kesimpulan: Kecuali singkong dan bentul, semua pangan yang diuji adalah pangan sumber karbohidrat yang direkomendasikan untuk penderita diabetes.
\end{abstract}

Kata kunci: pangan sumber karbohidrat, kandungan glukosa, indeks glikemik rendah 


\section{PENDAHULUAN}

Dewasa ini pertimbangan konsumen dalam memilih bahan pangan bukan hanya kandungan gizi atau kelezatannya, tetapi juga pengaruhnya terhadap kesehatan. Pangan juga diandalkan dalam pemeliharaan kesehatan dan pencegahan penyakit, bahkan jika memungkinkan pangan harus dapat menyembuhkan atau menghilangkan efek negatif penyakit tertentu (bersifat fungsional). Diabetes Mellitus (DM) adalah penyakit akibat gangguan metabolisme karbohidrat, lemak, dan protein dengan gejala berupa hiperglikemia kronik, yang dapat disebabkan antara lain oleh defisiensi sekresi atau aktivitas insulin, atau keduanya. Saat ini terjadi kecenderungan peningkatan penderita DM di seluruh dunia. Tahun 2014, 8,5\% dari usia 18 tahun ke atas terkena diabetes (WHO, 2016). Tahun 2012, DM adalah penyebab langsung 1,5 juta kematian dan kadar glukosa darah yang tinggi adalah penyebab kematian 2,2 juta lainnya. Indonesia adalah salah satu dari 10 negara di Asia dengan jumlah penderita DM terbanyak. Secara epidemiologi, diperkirakan bahwa pada tahun 2030 prevalensi DM di Indonesia mencapai 21,3 juta orang (Pusat Data dan Informasi, 2014).

Pengelolaan diabetes dilakukan dengan tiga cara, yaitu: obat antidiabetik oral, insulin, dan diet. Mengelola diabetes melalui diet berarti menerapkan pola makan seimbang dan membatasi diet secara terkendali (terapi nutrisi), yang berlaku untuk semua penderita diabetes. Untuk diabetes tipe-1 diperlukan keseimbangan asupan makanan dan suntikan insulin untuk mencapai kadar glukosa darah yang terkendali sedangkan untuk diabetes tipe-2, dalam beberapa kasus, pola diet yang baik saja sudah dapat mengendalikan kadar glukosa darah. Dalam terapi nutrisi, asupan glukosa dan karbohidrat dibatasi dan disesuaikan dengan kebutuhan tubuh (Di Piro dkk., 2008).

Indeks glikemik (IG) adalah salah satu konsep penting yang diajukan dalam memilih makanan yang sesuai bagi penderita DM. IG adalah ukuran kecepatan suatu pangan meningkatkan kadar glukosa darah setelah dikonsumsi (Riccardi dkk., 2008). Nilai IG rendah adalah di bawah 55, IG sedang di antara 55 sampai 69, dan IG tinggi di atas 70 (Atkinson dkk., 2008). Pangan sumber karbohidrat dengan IG rendah dicerna dan diabsorbsi lebih lambat dibandingkan pangan IG tinggi. Berbagai penelitian menunjukkan bahwa diet pangan IG rendah mampu menurunkan resistensi insulin pada penderita
DM sedangkan pada individu normal, diet pangan IG rendah dapat menurunkan obesitas sehingga mengurangi faktor resiko berbagai penyakit metabolik dan penyakit degeneratif (Marsh dkk., 2011).

Beberapa faktor yang berpengaruh terhadap nilai IG antara lain: jenis komponen monosakarida dalam bahan pangan, jenis karbohidrat, proses pengolahan pangan, dan komponen lain, seperti: lemak, protein, serat, antinutrien, dan asam organik (Leoro dkk., 2010). Glukosa adalah gula monosakarida yang dapat langsung diserap oleh tubuh dan dikonversi menjadi energi. Kadar glukosa dalam bahan pangan sumber karbohidrat meliputi: monosakarida yang sudah tersedia atau berasal dari pemecahan polisakarida (pati/amilum) dalam bahan tersebut. Proses pemecahan polisakarida menjadi monosakarida dapat terjadi selama proses pengolahan pangan atau melalui hidrolisis selama polisakarida yang dikatalisis oleh asam dan enzim dalam saluran cerna (Wang \& Copeland, 2015).

Ketersediaan bahan pangan dengan IG rendah merupakan masalah utama bagi penduduk Indonesia. Makanan pokok bagi sebagian besar penduduk Indonesia adalah nasi, sementara nasi memiliki IG sebesar $92 \pm 6$, yang termasuk IG tinggi (Foster-Powell dkk., 2002), sehingga penderita DM yang terbiasa mengkonsumsi nasi perlu menyesuaikan porsinya. Meskipun demikian, keanekaragaman hayati di Indonesia menjadi sumber karbohidrat yang dapat dieksplor untuk mengatasi masalah tersebut. Di daerah-daerah tertentu dijumpai konsumsi bahan pangan, seperti: jagung, sagu, ketela pohon, bahkan sorgum. Pada penelitian ini dilakukan uji indeks glikemik berbagai bahan pangan sumber karbohidrat yang dikonsumsi oleh masyarakat Indonesia, yaitu dari kelompok biji-bijian, umbi-umbian, buahbuahan, serta kacang-kacangan, yang sebelumnya telah ditentukan kandungan glukosanya.

Untuk menentukan kadar glukosa dalam pangan uji digunakan metode Luff-Schoorl. Pada metode ini, glukosa ditetapkan berdasarkan sifat reduksinya terhadap ion tembaga (II) dalam pereaksi Luff-Schoorl sehingga dinyatakan sebagai gula pereduksi. Pada penentuan IG, sampel pangan uji diberikan dalam jumlah yang setara dengan kandungan glukosa dalam setiap sampel pangan uji, yang telah ditentukan dengan metode Luff-Schoorl. Berbeda dengan penelitian tentang penentuan IG yang biasanya menggunakan subyek manusia, pada penelitian ini dilakukan pada hewan coba kelinci. 
Permasalahan dalam penelitian ini adalah (1) bagaimana profil indeks glikemik yang dimiliki oleh berbagai bahan pangan sumber karbohidrat yang diuji dan (2) apakah pangan uji mempunyai IG lebih rendah dibanding nasi beras putih. Tujuan penelitian ini adalah: menentukan kadar glukosa dalam 11 bahan pangan uji, menentukan IG pangan tersebut, dan mengelompokkannya ke dalam IG rendah, sedang, atau tinggi. Dari penelitian ini dapat diperoleh bahan pangan sumber karbohidrat ber-IG rendah yang dapat dijadikan sebagai pangan pengganti nasi untuk diet penderita Diabetes Mellitus.

\section{BAHAN DAN METODE Bahan}

Bahan pangan yang diuji meliputi: beras putih, beras merah, jagung, sorgum dari kelompok biji-bijian; singkong dan bentul dari kelompok umbi-umbian; pisang dan sukun dari kelompok buah-buahan; kacang hijau dan kacang merah dari kelompok kacang-kacangan.

Bahan kimia yang digunakan: asam klorida $(\mathrm{HCl})$, asam sitrat, asam sulfat $\left(\mathrm{H}_{2} \mathrm{SO}_{4}\right)$, etanol, Kalium Iodida (KI), tembaga (II) sulfat $\left(\mathrm{CuSO}_{4}\right)$, natrium karbonat $\left(\mathrm{Na}_{2} \mathrm{CO}_{3}\right)$, natrium hidroksida $(\mathrm{NaOH})$, dan natrium tiosulfat $\left(\mathrm{Na}_{2} \mathrm{~S}_{2} \mathrm{O}_{3}\right), \quad\left(\mathrm{NH}_{4}\right)_{2} \mathrm{HPO}_{4}$, amilum soluble semuanya berkualitas untuk analisis dari Merck.

Alat

Alat yang digunakan meliputi: neraca analitik, seperangkat alat refluks, desikator, seperangkat alat gelas, timer, sonde. Untuk penentuan kadar glukosa darah digunakan Glukometer One Touch Glucose Blood System.

\section{Hewan coba}

Hewan coba yang digunakan adalah kelinci (Ortycolagus cuniculus) dari bangsa New Zealand White yang diperoleh dari Pusat Veterinaria Farma (Pusvetma) Surabaya, jenis kelamin jantan, berat badan $1,5-2,5 \mathrm{Kg}$, umur 2,5-3 bulan, dan glukosa darah normal 60-120 mg/dL. Uji indeks glikemik dilakukan sesuai dengan protokol yang disetujui oleh komite etik penelitian Fakultas Kedokteran Hewan Universitas Airlangga (Ethical Clearence 303-KE).

\section{Metode}

\section{Preparasi sampel bahan pangan}

Bahan pangan diolah secara sederhana seperti yang umum dilakukan oleh masyarakat sehingga diperoleh makanan yang matang dan layak dikonsumsi. Beras putih, beras merah, jagung, sorgum ditanak selama waktu tertentu sampai menjadi nasi; singkong, bentul, pisang kapok, dan sukun dikukus selama waktu tertentu sehingga empuk; kacang hijau dan kacang merah direbus selama waktu tertentu sehingga lunak, buah pisang ambon yang matang tidak perlu diolah.

\section{Preparasi sampel untuk penentuan kadar glukosa.}

10 gram sampel halus ditambah air suling $20 \mathrm{~mL}$ dan diaduk selama satu jam, kemudian disaring dengan kertas saring Whatman no. 40. Filtrat ditambah $5 \mathrm{~mL}$ larutan $\mathrm{Zn}$-asetat dan setetes larutan $\left(\mathrm{NH}_{4}\right)_{2} \mathrm{HPO}_{4} 10 \%$ sampai timbul endapan putih, kemudian ditambahkan lagi larutan $\left(\mathrm{NH}_{4}\right)_{2} \mathrm{HPO}_{4}$ sampai tidak timbul kekeruhan dan ditambahkan air suling sampai $100 \mathrm{~mL}$. Filtrat ditambah $50 \mathrm{~mL}$ air suling dan $20 \mathrm{~mL} \mathrm{HCl} \mathrm{30 \%} \mathrm{dan} \mathrm{dipanaskan}$ dalam penangas air $60{ }^{\circ} \mathrm{C}$ selama 10 menit. Larutan didinginkan dengan cepat hingga suhu $20^{\circ} \mathrm{C}$ dan dinetralkan dengan $\mathrm{NaOH} 45 \%$. Dilakukan penyaringan kembali dan filtrat ditampung (disebut Filtrat A).

Residu dicuci dengan eter 3 kali, kemudian eter diuapkan. Residu ditambah $200 \mathrm{~mL}$ air suling dan $20 \mathrm{~mL}$ $\mathrm{HCl} 25 \%$, kemudian direfluks 2,5 jam dalam penangas air. Larutan didinginkan hingga suhu kamar dan dinetralkan dengan $\mathrm{NaOH} 45 \%$ kemudian disaring, filtrat yang ditampung disebut Filtrat B. Filtrat A dicampur dengan Filtrat B dan ditambah air suling sampai 500,0 mL.

\section{Penentuan kadar gula pereduksi}

Sampel hasil preparasi diencerkan secukupnya. $10,0 \mathrm{~mL}$ larutan hasil pengenceran ditambah larutan Luff-Schoorl 25,0 $\mathrm{mL}$ dan dididihkan dalam dua menit, kemudian diteruskan selama 10 menit. Larutan segera didinginkan dan ditambah $10 \mathrm{~mL}$ larutan KI $20 \%$ dan $25 \mathrm{~mL}$ larutan $\mathrm{H}_{2} \mathrm{SO}_{4} 6 \mathrm{~N}$ secara perlahan. Kemudian dilakukan titrasi dengan larutan $\mathrm{Na}_{2} \mathrm{~S}_{2} \mathrm{O}_{3}$ baku menggunakan indikator larutan amilum 0,5\% (misalnya dibutuhkan $V_{1} \mathrm{~mL} \mathrm{Na}_{2} \mathrm{~S}_{2} \mathrm{O}_{3}$ ).

Dilakukan penetapan blanko terhadap campuran $25 \mathrm{~mL}$ air dan $25 \mathrm{~mL}$ larutan Luff Schoorl yang telah dididihkan (misalnya dibutuhkan $V_{2} \mathrm{~mL} \mathrm{Na}_{2} \mathrm{~S}_{2} \mathrm{O}_{3}$ ). Kadar glukosa dinyatakan sebagai gula pereduksi $(\mathrm{g} / 100 \mathrm{~g})$ yang dihitung dengan rumus sebagai berikut:

$$
\% \text { gula pereduksi }=\frac{W_{1} \cdot f_{\mathrm{p}}}{W} \times 100 \%
$$

$W_{1}=$ berat glukosa $(\mathrm{mg}), f_{\mathrm{p}}=$ faktor pengenceran, $W=$ bobot sampel $(\mathrm{mg})$. $W_{1}$ adalah $\left(V_{2}-V_{l}\right)$ yang dikonversi menjadi berat $(\mathrm{mg})$ glukosa menggunakan tabel Luff-Schoorl. (International Starch Institute, 2002). 


\section{Penentuan indeks glikemik}

Penentuan indeks glikemik bahan pangan dilakukan pada hewan coba kelinci, untuk tiap sampel pangan uji digunakan satu kelompok yang terdiri dari 6 ekor. Kelinci pada tiap kelompok diberi pangan uji dosis setara $10 \mathrm{~g} / \mathrm{Kg}$ glukosa untuk manusia dewasa. Setelah masa istirahat kelinci dalam kelompok yang sama diberi pangan standar, glukosa 0,47 g/ Kg berat badan kelinci. Sebelum diberi perlakuan serta diukur kadar glukosa darahnya, kelinci dipuasakan semalam (tidak diberi makan, tetap minum ad libitum).

Berat badan kelinci ditimbang, kadar glukosa diukur dari darah vena telinga pada menit ke- 0 . Kelinci pada tiap kelompok kemudian diberi sediaan pangan uji, 30 menit kemudian diambil cuplikan darah dan ditentukan kadar glukosanya. Pengukuran glukosa darah selanjutnya dilakukan pada 15, 30, 60, 90, dan 120 menit setelah pemberian sediaan. Kelinci pada tiap kelompok diistirahatkan selama 4 hari, kemudian kelinci diberi larutan glukosa dan dilakukan pengukuran glukosa dilakukan dengan prosedur yang sama.

Dibuat kurva kadar glukosa darah rata-rata terhadap waktu pengukuran untuk tiap kelompok pangan uji dan pangan standar, kemudian dihitung luas daerah di bawah kurva (AUC) masing-masing. Indeks glikemik pangan uji dihitung dengan rumus: $\mathrm{IG}=$ (AUC pangan uji/AUC glukosa) x 100. (BPOM, 2011).

\section{HASIL DAN PEMBAHASAN}

Kadar glukosa dalam sampel pangan uji ditentukan secara Iodometri, yaitu larutan sampel yang telah direaksikan dengan pereaksi Luff-Schoorl dititrasi dengan larutan $\mathrm{Na}_{2} \mathrm{~S}_{2} \mathrm{O}_{3}$, yang telah dibakukan dengan $\mathrm{KIO}_{3}$. Selisih volume $\mathrm{Na}_{2} \mathrm{~S}_{2} \mathrm{O}_{3}$ pada titrasi blanko dengan volume $\mathrm{Na}_{2} \mathrm{~S}_{2} \mathrm{O}_{3}$ pada titrasi sampel adalah volume titran $\mathrm{Na}_{2} \mathrm{~S}_{2} \mathrm{O}_{3}$ yang digunakan untuk menghitung kadar glukosa dalam sampel sebagai gula pereduksi, dengan cara konversi menjadi berat menggunakan tabel LuffSchoorl. Kadar glukosa pangan uji ditampilkan pada Tabel 1.

Pada Tabel 1 juga ditampilkan hasil penentuan Indeks Glikemik. Data pada Tabel 1 memperlihatkan sorgum kukus mempunyai IG rendah, tetapi masih lebih tinggi dibanding IG pisang ambon, yang kadar glukosanya lebih tinggi. Tampaknya kadar glukosa pada pisang tidak berkaitan dengan peningkatan IG karena kadar glukosa diukur sebagai gula pereduksi total, sedangkan jenis gula monosakarida pada pisang tidak seluruhnya glukosa. Pada pisang terdapat fruktosa yang juga termasuk gula pereduksi (Adedayo dkk., 2016).

Tabel 1. Kadar glukosa dan Indeks Glikemik pangan uji

\begin{tabular}{lcc}
\hline Pangan uji* & $\begin{array}{c}\text { Kadar glukosa } \\
(\mathbf{g} / \mathbf{~ 1 0 0} \text { g) }\end{array}$ & $\begin{array}{c}\text { Indeks } \\
\text { Glikemik }\end{array}$ \\
\hline Beras Putih & $25,40(0,20)$ & 82 \\
Beras Merah & $23,03(0,77)$ & 47 \\
Jagung & $17,05(0,07)$ & 62 \\
Sorgum & $7,34(0,81)$ & 43 \\
Singkong & $22,66(1,21)$ & 79 \\
Bentul & $20,41(3,18)$ & 71 \\
Pisang kepok & $23,06(0,73)$ & 43 \\
Pisang Ambon** & $19,12(0,66)$ & 33 \\
Sukun & $13,84(1,34)$ & 65 \\
Kacang hijau*** & $24,58(1,21)$ & 50 \\
Kacang merah*** & $12,16(0,38)$ & 41
\end{tabular}

*bahan pangan diolah dengan cara dikukus, ** tidak diolah; *** diolah dengan cara direbus. Angka dalam kurung menunjukkan standar deviasi dari 6 replikasi;

Berdasarkan data pada Tabel 1, untuk membandingkan kadar glukosa pangan uji diurutkan dari kadar glukosa paling rendah. Pangan uji yang mempunyai kadar glukosa paling rendah adalah sorgum kukus, diikuti oleh kacang merah dan kacang hijau rebus, kemudian jagung kukus, pisang ambon dan seterusnya. Dapat dilihat bahwa sorgum kukus mempunyai kadar glukosa paling rendah, sedangkan nasi beras putih menunjukkan kadar paling tinggi.

Dari uji ANOVA untuk kadar glukosa dalam pangan uji diperoleh nilai $\mathrm{P}=0,00(<0,05)$, yang menunjukkan ada perbedaan bermakna pada kadar gula di antara pangan uji. Hasil uji LSD setelah ANOVA menunjukkan ada beberapa pangan uji yang kadar glukosanya tidak berbeda secara bermakna, ditampilkan pada Tabel 2.

Pada Tabel 2 dapat dilihat beberapa pangan uji mempunyai kadar glukosa yang sama meskipun berasal dari kelompok yang berbeda. Sebagai contoh, kadar glukosa pada singkong sama dengan beras merah, kadar glukosa pada pisang kepok sama dengan beras merah dan bentul, kadar glukosa pada kacang hijau sama dengan beras putih dan beras merah, serta kadar glukosa pada 
kacang merah sama dengan sukun. Glukosa pada pisang (yang manis rasanya) lebih banyak yang berasal dari monosakarida sedangkan kadar glukosa yang diperoleh dari beras, umbi-umbian, dan kacang-kacangan lebih banyak berasal dari hidrolisis pati. Jenis pati dalam bahan pangan akan mempengaruhi nilai Indeks Glikemik (Zhang \& Hamaker, 2009). Perbandingan kadar glukosa dalam pangan uji dapat dilihat pada Gambar 1.

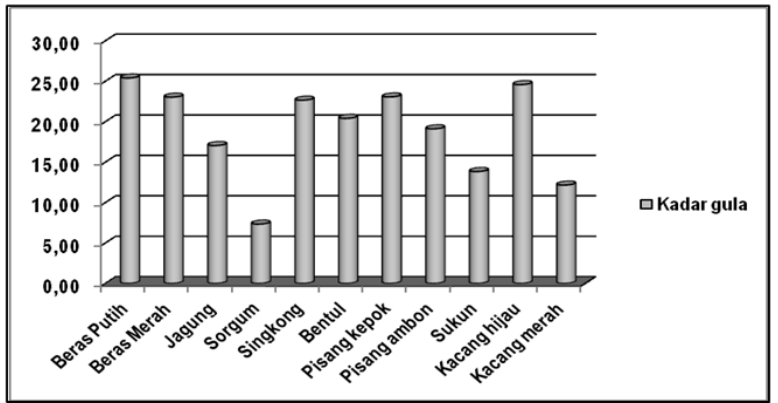

Gambar 1. Diagram batang kadar gula pereduksi dalam pangan uji

Tabel 2. Matriks beda rata-rata kadar glukosa dalam pangan uji hasil analisis LSD pada taraf kemaknaan 5\%

\begin{tabular}{|c|c|c|c|c|c|c|c|c|c|c|c|c|}
\hline \multirow{2}{*}{ No } & \multirow{2}{*}{ Pangan Uji } & \multicolumn{11}{|c|}{ No urut pangan uji } \\
\hline & & 1 & 2 & 3 & 4 & 5 & 6 & 7 & 8 & 9 & 10 & 11 \\
\hline 1 & Beras putih & 0 & & & & & & & & & & \\
\hline 2 & Beras merah & 2,06 & 0 & & & & & & & & & \\
\hline 3 & Jagung & 7,91 & 5,86 & 0 & & & & & & & & \\
\hline 4 & Sorgum & 18,05 & 16,00 & 10,14 & 0 & & & & & & & \\
\hline 5 & Singkong & 2,73 & $0,67^{*}$ & $-5,18$ & $-15,32$ & 0 & & & & & & \\
\hline 6 & Bentul & 4,99 & 2,93 & $-2,93$ & $-13,06$ & 2,26 & 0 & & & & & \\
\hline 7 & Pisang kepok & 2,33 & $0,28^{*}$ & $-5,58$ & $-15,72$ & $-0,40 *$ & $-2,66$ & 0 & & & & \\
\hline 8 & Pisang Ambon & 6,28 & 4,22 & $-1,63^{*}$ & $-11,77$ & 3,55 & $1,29 *$ & 3,95 & 0 & & & \\
\hline 9 & Sukun & 11,56 & 9,50 & 3,64 & $-6,50$ & 8,83 & 6,57 & 9,22 & 5,28 & 0 & & \\
\hline 10 & Kacang Hijau & $0,81 *$ & $-1,25^{*}$ & $-7,10$ & $-17,24$ & $-1,92$ & $-4,18$ & $-1,52 *$ & $-5,47$ & $-10,75$ & 0 & \\
\hline 11 & Kacang Merah & 13,24 & 11,18 & 5,32 & $-4,82$ & 10,51 & 8,25 & 10,90 & 6,96 & $1,68^{*}$ & 12,43 & 0 \\
\hline
\end{tabular}

* tidak menunjukkan perbedaan bermakna $(\mathrm{P}>0,05)$

Pada Gambar 1 tampak kadar glukosa dalam nasi sorgum paling rendah sehingga berpotensi mempunyai IG rendah. Monosakarida dalam sorgum sebagian besar dari hidrolisis pati sehingga sorgum membutuhkan waktu lebih lama untuk menghasilkan glukosa dibanding kacang merah. Demikian pula jika dibandingkan dengan sukun dan jagung. Kacang merah mempunyai kulit biji yang lebih tebal sehingga dapat menghambat pemecahan pati, demikian pula jagung yang kulit bijinya lebih tebal daripada beras. Sedangkan sukun kukus, yang diolah tanpa kulitnya, mempunyai tekstur daging buah yang berserat sehingga dapat menghambat pemecahan pati.

Nilai IG dihitung berdasarkan kadar glukosa darah yang diamati selama 2 jam setelah pemberian pangan uji dibandingkan dengan kadar glukosa darah setelah pemberian pangan standar (glukosa). Profil glukosa darah setelah pemberian pangan uji yang setara dengan 10 g glukosa pada manusia ditunjukkan pada Gambar 2. Gambar yang ditampilkan adalah 4 pangan uji yang mempunyai nilai IG rendah, yaitu pisang ambon, nasi sorgum, pisang kepok kukus, kacang merah rebus.

Pada Gambar 2 tampak peningkatan kadar glukosa darah pada pemberian nasi sorgum terjadi lebih cepat pada menit awal, kemudian kadar glukosa mengalami penurunan, sedangkan kenaikan glukosa darah setelah pemberian pisang dan kacang merah relatif lebih stabil. Hal ini yang menghasilkan AUC glukosa darah pada sorgum lebih tinggi dibanding pisang sehingga nilai IG sorgum lebih tinggi pula. Perbandingan nilai IG pangan uji ditampilkan pada Gambar 3. 


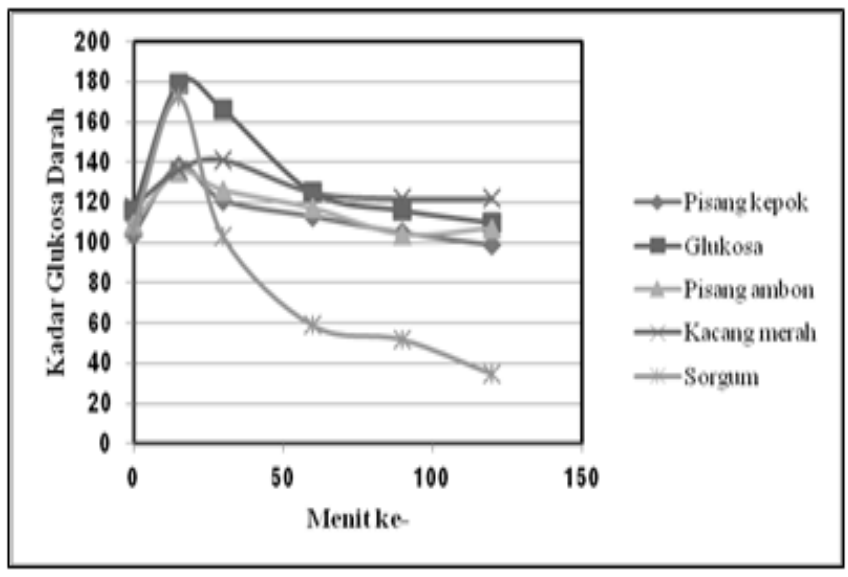

Gambar 2. Profil glukosa darah kelinci pada 4 kelompok setelah pemberian pangan uji dibandingkan dengan pemberian glukosa

Pada Gambar 3 dapat dilihat nasi beras putih termasuk pangan ber-IG tinggi berdasarkan uji pada kelinci, sama dengan hasil uji pada manusia (Kaur dkk., 2016) sehingga hasil penelitian ini dapat dijadikan acuan untuk mengevaluasi IG pangan uji pada manusia. Semua pangan yang diuji mempunyai IG lebih rendah dibanding nasi beras putih. Pangan uji dapat dikelompokkan berdasarkan Indeks Glikemiknya dalam Tabel 3.

Tabel 3. Pengelompokan pangan uji berdasarkan Indeks Glikemiknya

\begin{tabular}{lll}
$\begin{array}{ll}\text { IG Rendah } \\
<\mathbf{5 0}\end{array}$ & $\begin{array}{l}\text { IG Sedang } \\
\mathbf{5 1 - 7 0}\end{array}$ & $\begin{array}{l}\text { IG Tinggi } \\
\mathbf{7 0}\end{array}$ \\
\hline $\begin{array}{l}\text { pisang ambon } \\
\text { kacang merah rebus }\end{array}$ & $\begin{array}{l}\text { jagung kukus } \\
\text { sukun kukus }\end{array}$ & $\begin{array}{l}\text { bentul kukus } \\
\text { singkong kukus }\end{array}$ \\
$\begin{array}{l}\text { nasi sorgum } \\
\text { pisang kepok kukus } \\
\text { nasi beras merah } \\
\text { kacang hijau rebus }\end{array}$ & nasi beras putih \\
\hline
\end{tabular}

Berdasarkan Tabel 3. bahan pangan sumber karbohidrat yang diuji terbagi dalam kelompok IG rendah, sedang, dan tinggi. Yang dapat dijadikan alternatif pengganti nasi beras putih adalah yang termasuk kelompok IG rendah dan IG sedang.

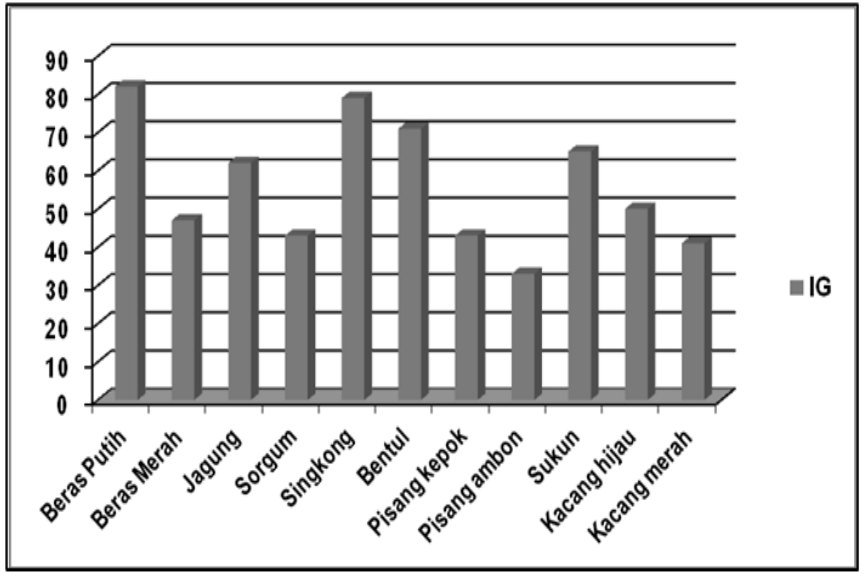

Gambar 3. Diagram batang indeks glikemik (IG) pangan uji

\section{KESIMPULAN}

Dapat ditarik kesimpulan bahwa kadar glukosa yang terkandung dalam bahan pangan sumber karbohidrat kelompok biji-bijian, umbi-umbian, buah-buahan, dan kacang-kacangan bervariasi bergantung pada jenis bahan. Semua bahan pangan yang diuji mempunyai Indeks Glikemik lebih rendah dibanding nasi beras putih tetapi singkong kukus dan bentul kukus masih tergolong pangan dengan IG tinggi. Bahan pangan yang dapat dijadikan alternatif bagi penderita Diabetes Mellitus meliputi: pisang ambon, kacang merah rebus, nasi sorgum, pisang kepok kukus, nasi beras merah, kacang hijau rebus dari kelompok IG rendah, serta jagung kukus dan sukun kukus dari kelompok IG sedang.

Untuk diet penderita DM bahan pangan tersebut sebaiknya diolah dengan cara yang sama seperti pada penelitian, yaitu dikukus atau direbus. Mengingat bahan pangan uji kelompok umbi-umbian dalam penelitian ini (singkong dan bentul) ternyata mempunyai IG tinggi, perlu dilakukan eksplorasi untuk mencari umbi-umbi lain yang mempunyai IG lebih rendah.

\section{UCAPAN TERIMA KASIH}

Terima kasih kami sampaikan kepada Fakultas Farmasi Universitas Airlangga yang telah memberikan dukungan dana penelitian dari Project Grant Fakultas Farmasi, serta fasilitas yang diperlukan untuk penelitian. 


\section{DAFTAR PUSTAKA}

Adedayo, B. C., Oboh, G., Oyeleye, S. I., Tosin, A. \& Olasehinde, T. A. (2016). Antioxidant and Antihyperglycemic Properties of Three Banana Cultivars (Musa spp.). Scientifica; 2016; 839-46.

Atkinson, F. S., Foster-Powell, K. \& rand-Miller, J.C. (2008). International table of glycemic index and glycemic load values: 2008. Diabetes Car; 31; 2281-83.

BPOM RI. (2011). Lampiran VI Peraturan Kepala Badan Pengawas Obat Dan Makanan No. HK.03.1.23.12.11.09909 Tahun 2011 Tentang Pengawasan Klaim Dalam Label Dan Iklan Pangan Olahan. Metode Standar Penentuan Indeks Glikemik Pangan.

Di Piro, J. T., Talbert, R. L., Yee, G. C., Matzke, G. R., Wells, B. G. \& Posey, L. M. (2008). Pharmacotherapy. A Pathophysiologic Approach. $7^{\text {th }} E d s ; 1205-40$.

Foster-Powell, K., Holt, S. H. A. \& Brand-Miller, J. C. (2002). International table of glycemic index and glycemic load values: 2002. Am J Clin Nutr; 76; 5-56.

International Starch Institute. (2002). Denmark International Standard: ISO 5377ISI 28-1e Determination of Reducing Sugar, DE by LuffSchoorl's method. Science Park Aarhus, Copenhagen.
Kaur, B., Ranawana, V. \& Henry J. (2016). The Glycemic Index of Rice and Rice Products: A Review, and Table of GI Values. J Critical Rev in Food Sci and Nutr; 56(2); 215-36.

Leoro, M. G. V., Clerici, M. T. P. S., Chang, Y. K. \& Steel C.J. (2010). Cienc Tecnol Aliment; 30(4); 964-68.

Marsh, K., Barclay, A. \& Colagiuri, S. (2011). Glycemic Index and Glycemic Load of Carbohydrates in the Diabetes Diet. Curr Diab Rep; 11; 20-27.

Pusat Data dan Informasi Kementrian Kesehatan RI. (2014). Analisis Situasi Diabetes. Riset Kesehatan Dasar Tahun 2013.

Riccardi, G., Rivellese, A. A. \& Giacco, R. (2008). Role of Glycemic index and glycemic load in the healthy state, in prediabetes, and in diabetes. $A m J$ Clin Nutr; 87; 269-74.

WHO. (2016). Global Report on Diabetes. Press Release. Geneva.

Wang, S. \& Copeland L. (2015). Effect of Acid Hydrolysis on Starch Structure and Functionality: A Review. J Critical Rev in Food Sci and Nutr; 55(8); 1081-97.

Zhang, G. \& Hamaker, B. R. (2009). Slowly Digestible Starch: Concept, Mechanism, and Proposed Extended Glycemic Index. J Critical Rev in Food Sci and Nutr; 49(10); 852-67. 